\title{
РІВЕНЬ СТОМАТОЛОГІЧНОЇ ГІГІЄНІЧНОЇ ГРАМОТНОСТІ НАСЕЛЕННЯ
}

\section{Рівень стоматологічної гігієнічної грамотності населення}

\section{Н. В. Манащук, Н. В. Чорній, С. І. Бойцанюк}

Тернопільський національний медичний університет імені І. Я. Горбачевського МОЗ України

Резюме. Важлива роль у досягненні успіху лікування захворювань зубів та ясен належить умінню лікарястоматолога навчити пацієнта навичкам індивідуальної гігієни ротової порожнини, сформувати мотивацію до здійснення гігієнічних заходів та переконати у важливості підтримувальної терапії. На сьогодні ступінь обізнаності пацієнтів відносно питань гігієни ротової порожнини повинен бути кращим.

Мета дослідження - вивчити рівень стоматологічної гігієнічної грамотності населення.

Матеріали і методи. Виконано анонімне анкетування 197 осіб, жителів міста Тернополя, відносно питань гігієни ротової порожнини під час проведення Європейського дня здорових ясен.

Результати. У статті подано результати анкетування громадян відносно їх гігієнічного догляду за ротовою порожниною та наявності певних симптомів захворювань пародонта. Виділено групу ризику в даних патологіях.

Висновки. Результати анкетування показали досить непоганий рівень гігієнічного виховання населення відносно ротової порожнини. При цьому за допомогою простих запитань вдалось виділити групу ризику серед населення із захворювань тканин пародонта.

Ключові слова: гігієна ротової порожнини; кровоточивість; рухомість зубів.

\section{ВСТУП}

Однією із причин виникнення карієсу та гінгівіту і важливим патогенетичним чинником їхнього подальшого розвитку є мікробна зубна бляшка, яка утворюється унаслідок недостатньої гігієни ротової порожнини [1-3]. Метою гігієни ротової порожнини є очищення зубів від залишків їжі та набутих структур (зубної бляшки і м'якого зубного нальоту), детриту, мікрофрлори [4]. Крім цього, гігієна ротової порожнини має на меті й внесення різних засобів (методами полоскання, зрошення та аплікацій), які позитивно впливають на властивості її органів, зміцнюють їхню резистентність і фрункціональні можливості $[1,5]$.
Level of dental hygienic education of the population

N. V. Manashchuk, N. V. Chorniy, S. I. Boytsanyuk

I. Horbachevsky Ternopil National Medical University

e-mail: manashchukn@tdmu.edu.ua

Summary. An important role in the success of the treatment of dental and gum diseases belongs to the ability of the dentist to teach the patient the skills of individual oral hygiene, to form the motivation to take hygienic measures and to convince of the importance of maintenance therapy. Unfortunately, today the level of awareness of patients about oral hygiene requires to be better.

The aim of the study - to learn the level of dental hygienic education of the population.

Materials and Methods. An anonymous questionnaire of 197 people, residents of Ternopil about oral hygiene was conducted during the European Day of Healthy Gum.

Results. The article presents the results of a questionnaire of people about their hygienic care of the oral cavity and the presence of certain symptoms of periodontal disease. The risk group for these pathologies was identified.

Conclusions. The results of the survey showed a fairly good level of hygienic education of the population relative to the oral cavity. At the same time, with the help of simple questions it was possible to identify the risk group among the population for periodontal diseases.

Key words: hygienic oral cavity; bleeding; tooth mobility.

Кожен візит до стоматолога повинен супроводжуватись навчанням пацієнта догляду за своєю ротовою порожниною [3]. Важлива роль у досягненні успіху лікування захворювань зубів та ясен належить умінню лікаря-стоматолога навчити пацієнта навичкам індивідуальної гігієни ротової порожнини, сфрормувати мотивацію до здійснення гігієнічних заходів та переконати у важливості підтримувальної терапії [4].

На сьогодні ступінь обізнаності пацієнтів відносно питань гігієни ротової порожнини повинен бути кращим.

Мета дослідження - вивчити рівень стоматологічної гігієнічної грамотності населення. 


\section{МАТЕРІАЛИ I МЕТОДИ}

Виконано анонімне анкетування 197 осіб, жителів міста Тернополя, відносно питань гігієни ротової порожнини під час проведення Європейського дня здорових ясен.

\section{РЕЗУЛЬТАТИ Й ОБГОВОРЕННЯ}

Колектив кафедри терапевтичної стоматології виконав анонімне анкетування жителів міста відносно питань гігієни ротової порожнини під час проведення Європейського дня здорових ясен, який проходив 11 травня 2019 року. Ми розробили анкету для опитування. Вона була анонімною, потрібно було лише вказати стать та вік опитуваного. Більшість запитань анкети стосувалась гігієни ротової порожнини.

Проанкетовано 197 осіб, з яких 132 жінки $(67,1 \%)$ та 65 чоловіків (32,9\%). Середній вік жінок складав $(30,1 \pm 1,29)$, а чоловіків - $(35,5 \pm 2,27)$ року.

Приємно відмітити, що більшість анкетованих непогано доглядає за ротовою порожниною. Так, 151 (76,6 \%) особа чистить зуби два рази на день, 34 (17,3\%) - один раз, а 12 осіб (6,1 \%) - більше двох разів. При цьому таких осіб, які не чистять взагалі, не було відмічено.

Необхідно зауважити, що більшість опитаних не могла чітко вказати якою конкретно зубною пастою і щіткою вони користуються. Аргументуючи це тим, що не задумуються над вибором, купуючи те, що, як правило, підходить за ціною. Також варто зазначити, що більшість (147 (74,6 \%)) осіб користується мануальними зубними щітками. I лише 50 $(25,4 \%)$ опитаних використовують для чищення своїх зубів електричні щітки.

Що стосується додаткових засобів гігієни, то тут отримані такі результати. Постійно користуються ополіскувачами 113 осіб, що складає 57,3 \%. При цьому вони також різні. Міжзубні проміжки чистять за допомогою фрлосів 49 чоловік (24,9\%). Необхідно зазначити, що тут опитані могли назва-

\section{СПИСОК ЛІТЕРАТУРИ}

1. Мельничук Г. М. Гінгівіт, пародонтит, пародонтоз: особливості лікування : навч. посіб. - 5-те вид., доповнене / Г. М. Мельничук, М. М. Рожко, Л. В. Завербна. - Івано-Франківськ, 2011. - 328 с.

2. Косенко К. Н. Профрилактическая гигиена полости рта / К. Н. Косенко, Т. П. Терешина. - Одесса : изд. КП ОГП, 2003. - 288 c.

3. Профрілактика стоматологічних захворювань / за ред. профр. Л. Ф. Каськової. - Харків : Факт, 2011. - 392 с. ти не лише фрірму виробника зубних ниток, але і конкретний їх вид.

Зубочистки використовують 71 (36,1 \%) людина, а жувальні гумки - 85 (43,1 \%) опитаних.

В анкеті було поставлено декілька запитань, що стосувалися відвідувань стоматолога та наявності симптомів, які можуть свідчити про певні захворювання.

Так, серед опитаних 78 осіб (39,6 \%) регулярно, двічі на рік звертаються до стоматолога, 50 осіб $(25,4 \%)$ - один раз і 69 опитаних $(35,1 \%)$ роблять це лише за потребою.

Відносно наявності певних симптомів, то тут 25 осіб (12,7 \%) відмічають постійну кровоточивість при чищенні зубів, 78 (39,6 \%) - періодично виникає, а 94 особи (74,6 \%) не спостерігають цього симптому взагалі.

Незначну рухомість зубів помічають 11,7 \% (23 особи), а у 88,3 \% зуби стійкі. Крім цього, 29 опитаних $(14,7$ \%) зауважують неприємний запах із рота, не пов'язаний із споживанням їжі.

Таким чином, серед усіх 197 анкетованих виділено групу з 25 осіб із наявними симптомами захворювань пародонта. Їм було дано рекомендації відносно звернення до стоматолога для подальшого детального обстеження.

\section{ВИСНОВКИ}

Як видно із результатів анкетування, рівень гігієнічного виховання населення відносно ротової порожнини досить непоганий. При цьому за допомогою простих запитань вдалось виділити групу ризику серед населення із захворювань тканин пародонта. До таких опитувань, можливо і більш розширених, необхідно залучати більшу кількість населення. Це дасть змогу виділяти певні групи, які необхідно ретельно обстежувати, що, у свою чергу, сприятиме профрілактиці виникненню та прогресуванню деяких захворювань ротової порожнини.

4. Улитовский С. Б. Средства гигиены полости рта как мотивация стоматологического здоровья / С. Б. Улитовский, Е. С. Алексеева, О. В. Калинкина // Пародонтология. - 2011. - Т. 16, № 2. - С. 65-66.

5. Улитовский С. Б. Гигиена полости рта в пародонтологии : монографрия / С. Б. Улитовский. - М. : Медицинская книга, 2006. - 268 с.

6. Улитовский С. Б. Гигиена полости рта - первичная профилактика стоматологических заболеваний / С. Б. Улитовский. - М., 1999. - 144 с. 


\section{REFERENCES}

1. Melnychuk HM, Rozhko MM, Zaverbna LV. Gingivitis, periodontitis, periodontitis: features of treatment: textbook 5th ed. Supplemented. [Гінгівіт, пародонтит, пародонтоз: особливості лікування : навч. посіб. - 5-те вид., доповнене] 2011; Ivano-Frankivsk. Ukrainian.

2. Kaskovova LF. Prophylactic hygiene of the oral cavity. [Профрилактическая гигиена полости рта] 2011; Odessa: KP OHT. Russian.

3. Kosenko KN, Tereshyna TP. Prevention of dental diseases. [Профрілактика стоматологічних захворювань] 2003; Kharkiv: Fakt. Ukrainian.
4. Ulytovskyi SB, Alekseeva ES. [Oral hygiene products as the motivation for dental health]. Parodontologiya. 2011;16 (2): 65-6. Russian.

5. Ulytovskyi SB. Oral hygiene in periodontology: Monograph. [Гигиена полости рта в пародонтологии : монографияя] 2006; Moscow: Medytsynskaya kniga. Russian.

6. Ulytovskyi SB. Oral hygiene - the primary prevention of dental diseases. [Гигиена полости рта - первичная профилактика стоматологических заболеваний] 1999; Moscow. Russian. 